\title{
Synthesis of Carbon-Supported $\mathrm{MnO}_{2}$ Nanocomposites for Supercapacitors Application
}

\author{
Jolita Jablonskiene *, Dijana Simkunaite, Jurate Vaiciuniene, Giedrius Stalnionis, Audrius Drabavicius, \\ Vitalija Jasulaitiene $(\mathbb{D}$, Vidas Pakstas, Loreta Tamasauskaite-Tamasiunaite $*$ (D) and Eugenijus Norkus (1)
}

Citation: Jablonskiene, J.; Simkunaite, D.; Vaiciuniene, J.; Stalnionis, G.; Drabavicius, A.; Jasulaitiene, V.; Pakstas, V.; Tamasauskaite-Tamasiunaite, L.; Norkus, E. Synthesis of Carbon-Supported $\mathrm{MnO}_{2}$ Nanocomposites for Supercapacitors Application. Crystals 2021, 11, 784. https://doi.org/10.3390/ cryst11070784

Academic Editor: Fabrizio Pirri

Received: 11 May 2021

Accepted: 1 July 2021

Published: 5 July 2021

Publisher's Note: MDPI stays neutral with regard to jurisdictional claims in published maps and institutional affiliations.

Copyright: (c) 2021 by the authors. Licensee MDPI, Basel, Switzerland. This article is an open access article distributed under the terms and conditions of the Creative Commons Attribution (CC BY) license (https:// creativecommons.org/licenses/by/ $4.0 /)$.
Center for Physical Sciences and Technology, Sauletekio Ave. 3, LT-10257 Vilnius, Lithuania; dijana.simkunaite@ftmc.lt (D.S.); jurate.vaiciuniene@ftmc.lt (J.V.); giedrius.stalnionis@ftmc.lt (G.S.); audrius.drabavicius@ftmc.lt (A.D.); vitalija.jasulaitiene@ftmc.lt (V.J.); vidas.pakstas@ftmc.lt (V.P.); eugenijus.norkus@ftmc.lt (E.N.)

* Correspondence: jolita.jablonskiene@ftmc.lt (J.J.); loreta.tamasauskaite@ftmc.lt (L.T.-T.)

\begin{abstract}
In this study, carbon-supported $\mathrm{MnO}_{2}$ nanocomposites have been prepared using the microwave-assisted heating method followed by two different approaches. The $\mathrm{MnO}_{2} / \mathrm{C}$ nanocomposite, labeled as sample S1, was prepared directly by the microwave-assisted synthesis of mixed $\mathrm{KMnO}_{4}$ and carbon powder components. Meanwhile, the other $\mathrm{MnO}_{2} / \mathrm{C}$ nanocomposite sample labeled as $\mathrm{S} 2$ was prepared indirectly via a two-step procedure that involves the microwave-assisted synthesis of mixed $\mathrm{KMnO}_{4}$ and $\mathrm{MnSO}_{4}$ components to generate $\mathrm{MnO}_{2}$ and subsequent secondary microwave heating of synthesized $\mathrm{MnO}_{2}$ species coupled with graphite powder. Field emission scanning electron microscopy (FE-SEM), transmission electron microscopy (TEM), X-ray photoelectron spectroscopy (XPS), and inductively coupled plasma optical emission spectroscopy have been used for characterization of $\mathrm{MnO}_{2} / \mathrm{C}$ nanocomposites morphology, structure, and composition. The electrochemical performance of nanocomposites has been investigated using cyclic voltammetry and galvanostatic charge/discharge measurements in a $1 \mathrm{M} \mathrm{Na}_{2} \mathrm{SO}_{4}$ solution. The $\mathrm{MnO}_{2} / \mathrm{C}$ nanocomposite, prepared indirectly via a two-step procedure, displays substantially enhanced electrochemical characteristics. The high specific capacitance of $980.7 \mathrm{~F} \mathrm{~g}^{-1}$ has been achieved from cyclic voltammetry measurements, whereas specific capacitance of $949.3 \mathrm{~F} \mathrm{~g}^{-1}$ at $1 \mathrm{~A} \mathrm{~g}^{-1}$ has been obtained from galvanostatic charge/discharge test for sample S2. In addition, the specific capacitance retention was $93 \%$ after 100 cycles at $20 \mathrm{~A} \mathrm{~g}^{-1}$, indicating good electrochemical stability.
\end{abstract}

Keywords: supercapacitors; microwave synthesis; nanocomposites; $\mathrm{MnO}_{2}$

\section{Introduction}

The development of high-performance, environmentally friendly, flexible, light and inexpensive energy storage devices has become one of the most significant worldwide concerns over the past few decades [1-4]. In this regard, supercapacitors (SCs) are widely viewed as potential candidates for next-generation energy storage devices $[5,6]$. They are of particular interest for high power capability, cyclic stability, safe and simple operation principle, and speedy charge dynamics compared to the other storage devices $[7,8]$.

The decisive role in the fabrication of efficient SCs is directly related to the intrinsic properties of the electrode material used [2,9]. Various new advanced nanostructured materials or their hybrid combinations of two or more components are being looked at. Currently, transition metal oxides (TMOs) coupled mainly with high-surface-area carbonbased materials have been allowed to achieve various hybrid SCs systems, which have superior characteristics of power and energy densities compared to those values obtained at each system separately $[10,11]$. Among the preferential TMO materials for SCs, a series of manganese oxide-based hybrids were developed recently [12-16]. Exceptional attention has been focused on $\mathrm{MnO}_{2}$ for its relatively low cost, environmental friendliness, natural abundance, multiple oxidation states of $\mathrm{Mn}$, wide operating voltage range (0-1.00 V vs. 
NHE in the neutral electrolyte), and high theoretical specific capacitance $\left(\mathrm{C}_{\mathrm{S}}\right)$ close to $1370 \mathrm{~F} \mathrm{~g}^{-1}[17,18]$.

However, regardless of the above-mentioned superb characteristics, the main drawback for $\mathrm{MnO}_{2}$ widespread application is relatively poor electronic $\left(10^{-5}-10^{-6} \mathrm{~S} \mathrm{~cm}^{-1}\right)$ and ionic $\left(10^{-13} \mathrm{~S} \mathrm{~cm}^{-1}\right)$ conductivity $[8,15]$. The experimentally achieved actual capacitance value is far below the theoretically predicted value and depends strongly on the mass loading of $\mathrm{MnO}_{2}$. Typically it decreases rapidly with the increase in the $\mathrm{MnO}_{2}$ mass [19]. To improve the capacitive performance of $\mathrm{MnO}_{2}$, several strategies have been proposed. Nanostructured $\mathrm{MnO}_{2}$-based electrodes with various morphologies have a high specific surface area and a large surface-to-volume ratio for more effective contact with electrolyte ions, such as mesoporous $\mathrm{MnO}_{2}$ nanotubes/nanosheets [20], nanowires [21], or flowerlike, urchinlike, and nano rodlike structures that have been developed. Multiple-phase heterostructures for high-capacitance electrodes have been created as well [22]. Two highcapacitance crystal phases of $\mathrm{MnO}_{2}$, namely $\alpha-\mathrm{MnO}_{2}$ nanowires and $\delta-\mathrm{MnO}_{2}$ ultrathin nanoflakes, have been combined and generated a self-branch heterostructure with a high $\mathrm{C}_{\mathrm{s}}$ value of $178 \mathrm{~F} \mathrm{~g}^{-1}$ at $5 \mathrm{mV} \mathrm{s}^{-1}$ [22].

To enhance the electric conductivity of $\mathrm{MnO}_{2}$, the incorporation of conductive metals including $\mathrm{Au}, \mathrm{Al}, \mathrm{Cu}, \mathrm{Fe}, \mathrm{Mg}, \mathrm{Co}$ [23-31] able to act as electron donors have been applied. Changes in electron structure by foreign heteroatoms resulted in the improved capacitive performance of $\mathrm{MnO}_{2}$ and revealed that, for example, $\mathrm{Cu}$-doped $\delta-\mathrm{MnO}_{2}$ film delivered the maximum $\mathrm{C}_{\mathrm{s}}$ value as high as $296 \mathrm{~F} \mathrm{~g}^{-1}$ at $1 \mathrm{~A} \mathrm{~g}^{-1}$ [26]; for Fe-doped $\mathrm{MnO}_{2}$ nanostructures, this value was of $267.0 \mathrm{~F} \mathrm{~g}^{-1}$ even under a high mass loading of $5 \mathrm{mg} \mathrm{cm}^{-2}$ [28]. In the presence of $\mathrm{Co}$, the achieved $\mathrm{C}_{\mathrm{s}}$ value was of $350 \mathrm{~F} \mathrm{~g}^{-1}$ at a current density of $0.1 \mathrm{~A} \mathrm{~g}^{-1}$ [29]. The Al-doped $\mathrm{MnO}_{2}$ demonstrated a high mass and areal specific capacitance of $213 \mathrm{~F} \mathrm{~g}^{-1}$ and $146 \mathrm{~F} \mathrm{~cm}^{-2}$, respectively, at $0.1 \mathrm{~A} \mathrm{~g}^{-1}$ [25]. Meanwhile, $\mathrm{Au}$-doped $\mathrm{MnO}_{2}$ showed a high $\mathrm{C}_{\mathrm{s}}$ value of $626 \mathrm{~F} \mathrm{~g}^{-1}$ at $5 \mathrm{mV} \mathrm{s}^{-1}$ [24].

However, the most effective and currently most widely used way to improve $\mathrm{C}_{\mathrm{s}}$ of $\mathrm{MnO}_{2}$-based electrodes is the deposition of thin films of latter materials on highly conductive and large surface areas containing materials, such as carbon-based substrates, including activated carbon, carbon nanotubes (CNTs), graphene, carbon fiber, or graphitic carbon. Carbon-based materials are the most widely used because of their physical and chemical properties, including low cost, variety of forms, low effort of processing, relatively inert electrochemistry, controllable porosity, and numerous electrocatalytic active sites for a variety of redox reactions [32-34] However, the performance of carbon-based substrates has some limitations related to the insufficient penetration of ions on the inert surface. Therefore, nanohybrids from two or more materials have been developed to overcome such limitations and gained special attention due to synergetic effects in enhancing the surface and electron donor properties. S.V. Prabhakar Vattikuti et al. reported $1 \mathrm{D} / 2 \mathrm{Dcarbon}-\mathrm{CuO}$-graphitic carbon nitride $\left(\mathrm{C} / \mathrm{CuO} @ \mathrm{~g}-\mathrm{C}_{3} \mathrm{~N}_{4}\right)$ ternary heterostructure that showed a better specific capacitance of $247.2 \mathrm{~F} \mathrm{~g}^{-1}$ compared with the pristine $\mathrm{g}-\mathrm{C}_{3} \mathrm{~N}_{4}$ of 83.7 $\mathrm{F} \mathrm{g}^{-1}$, at the same time possessing good stability, with $92.1 \%$ of the initial capacitance remaining even after 6000 cycles [35]. Newly designed nanohybrids with $\mathrm{Bi}_{2} \mathrm{~S}_{3}$ nanorod core@ amorphous carbon shell heterostructure $\mathrm{C} @ \mathrm{Bi}_{2} \mathrm{~S}_{3}$ displayed a high specific capacity of $333.43 \mathrm{~F} \mathrm{~g}^{-1}$ at a current density of $1 \mathrm{~A} \mathrm{~g}^{-1}$ and outperformed that of pristine $\mathrm{Bi}_{2} \mathrm{~S}_{3}$ of $124.24 \mathrm{~F} \mathrm{~g} \mathrm{~g}^{-1}$, due to well-defined cross linkages between the $\mathrm{Bi}_{2} \mathrm{~S}_{3}$ core and carbon shell [36]. The carbon layer was supposed to bind efficiently with $\mathrm{Bi}_{2} \mathrm{~S}_{3}$ nanorods, and thus improve electrical contact with the current collector, confirming the more active carbon participation in the charge/discharge reaction process. These highly porous structures allow the free permeation of electrolyte ensuring rapid movement of ions. Further on, a novel $\mathrm{Na}_{2} \mathrm{Ti}_{3} \mathrm{O}_{7}$ / single-walled carbon nanotubes SWCNTs nanostructure electrode material due to high surface area, enriched interfacial conductivity, abundant active edge sites, and mesoporous nature demonstrated a capacity of $576.01 \mathrm{~F} \mathrm{~g}^{-1}$, at $0.8 \mathrm{~A} \mathrm{~g}^{-1}$, with cycling stability featuring $91.43 \%$ retaining of capacitance after 5000 cycles [37]. 
Recently, a synergy of such carbon-based materials, featuring excellent conductivity and ultrastability, with $\mathrm{MnO}_{2}$ substances having less lower conductivity but larger electrochemical capacitance, has allowed overcoming limitations of each material separately by making full use of their advantages due to the synergistic effects between those two types of SCs materials [38-44]. Y. Ping et al. produced the hierarchically porous CJE/ $\mathrm{MnO}_{2}$ composite with a large specific capacitance of $283 \mathrm{~F} \mathrm{~g}^{-1}$ at $1 \mathrm{~A} \mathrm{~g}^{-1}$, which was on account of high specific surface area $\left(1283 \mathrm{~m}^{2} \mathrm{~g}^{-1}\right)$ and abundant active sites for pseudocapacitance, that particularly resulted from the introduction of $\mathrm{MnO}_{2}$ [38]. Meanwhile, highly loaded MnOx of $7.02 \mathrm{mg} \mathrm{cm}^{-2}$, electrodeposited on conductive carbon cloth allowed achieving excellent rate capability due to the dual-tuning effect and showed specific capacitance of $161.2 \mathrm{~F} \mathrm{~g}^{-1}\left(1.13 \mathrm{~F} \mathrm{~cm}^{-2}\right)$ at a high current density of $20 \mathrm{~mA} \mathrm{~cm}^{-2}$ [39]. Recently, an $\mathrm{MnO}_{2}$ nanowires/graphenated CNTs composite was grown in situ on $316 \mathrm{~L}$ stainless steel and exhibited a high capacitance of $495.2 \mathrm{mF} \mathrm{cm}^{-2}\left(615.6 \mathrm{~F} \mathrm{~g}^{-1}\right)$ at a current density of $0.5 \mathrm{~mA} \mathrm{~cm}^{-2}$ and $95 \%$ capacity retention after 5000 cycles due to the synergistic effects of the high conductivity of graphenated CNTs and high pseudocapacitance of $\mathrm{MnO}_{2}$ nanowires [42].

Bearing in mind that the structure of the electrode material directly affects the electrochemical properties of the electrode and simultaneously determines the performance of SCs, different methods have been tested to develop high capacitive $\mathrm{MnO}_{2}$-based electrode materials. Among them are such methods as hydrothermal synthesis [20,45,46], electrochemical deposition [42,47,48], electrochemical exfoliation [48], electrospinning [49], chemical coprecipitation [50], or even those, using templates [40]. Particular attention has been focused on the simple, fast, cost-effective, and reliable microwave-assisted approach. This method has several advantages that count the possibility to get great gain in energy savings and enhanced fabrication of homogeneous materials since they do not need expensive equipment or complicated procedures; microwave reactions take less time compared to conventional methods and overtake all the substance uniformly, providing uniform particle-size distribution in the sample. Recently, this approach was successfully introduced to synthesize $\mathrm{MnO}_{2}$ materials that proved themselves for possible use in high-performance supercapacitor applications [51-57].

In this study, the carbon-supported $\mathrm{MnO}_{2}$ nanocomposites $\left(\mathrm{MnO}_{2} / \mathrm{C}\right)$ were prepared by the rapid and simple microwave-assisted heating method by employing manganese(II) sulfate $\left(\mathrm{MnSO}_{4}\right)$ or potassium permanganate $\left(\mathrm{KMnO}_{4}\right)$ and carbon powder as the microwave absorbing material. The electrochemical properties of the prepared $\mathrm{MnO}_{2} / \mathrm{C}$ nanocomposites have been studied to evaluate the possibility of using these nanocomposites as potential supercapacitor electrode materials.

\section{Materials and Methods}

Graphite powder, $\mathrm{KMnO}_{4}, \mathrm{MnSO}_{4} \cdot \mathrm{H}_{2} \mathrm{O}, \mathrm{Na}_{2} \mathrm{SO}_{4}$, polyvinylidene fluoride ( $2 \%, \mathrm{PVDF}$ ), $\mathrm{N}$-methyl-2-pyrrolydone (NMP) were obtained from a Sigma-Aldrich supplier (Taufkirchen, Germany). All reagents were of analytical grade and used as received without further purification. Aqueous solutions were prepared using Milli-Q water with a resistivity of $18.2 \mathrm{M} \Omega \mathrm{cm}^{-1}$.

$\mathrm{MnO}_{2} / \mathrm{C}$ nanocomposite labeled as sample $\mathrm{S} 1$ was prepared by the following steps: $2 \mathrm{~g}$ of $\mathrm{KMnO}_{4}$ was mixed with $0.1 \mathrm{~g}$ of graphite powder and $20 \mathrm{~mL}$ of deionized water in an ultrasound bath for $30 \mathrm{~min}$. Then, the reaction mixture was put into a microwave reactor Monowave 300 (Anton Paar, Graz, Austria). The synthesis of $\mathrm{MnO}_{2} / \mathrm{C}$ was carried out at a temperature of $150^{\circ} \mathrm{C}$ for $5 \mathrm{~min}$. After that, the precipitate was filtered out, washed with deionized water, and dried in a vacuum oven at a temperature of $80{ }^{\circ} \mathrm{C}$ for $2 \mathrm{~h}$. Equation (1) describes the formation of $\mathrm{MnO}_{2}$ [18]:

$$
4 \mathrm{KMnO}_{4}+3 \mathrm{C}+\mathrm{H}_{2} \mathrm{O} \rightarrow 4 \mathrm{MnO}_{2}+\mathrm{K}_{2} \mathrm{CO}_{3}+2 \mathrm{KHCO}_{3}
$$

Another $\mathrm{MnO}_{2} / \mathrm{C}$ nanocomposite labeled as sample $\mathrm{S} 2$ was prepared by the following procedure: at first, the pure $\mathrm{MnO}_{2}$ was prepared. In a typical experiment, $0.063 \mathrm{~g}$ of $\mathrm{KMnO}_{4}$ 
and $0.1 \mathrm{~g}$ of $\mathrm{MnSO}_{4} \cdot \mathrm{H}_{2} \mathrm{O}$ was dispersed in $20 \mathrm{~mL}$ of deionized water and mixed in an ultrasound bath for $30 \mathrm{~min}$. Then, the reaction mixture was put into a microwave reactor, and the synthesis was carried out at a temperature of $150{ }^{\circ} \mathrm{C}$ for $5 \mathrm{~min}$. The precipitate was filtered out, washed with deionized water, and dried in a vacuum oven at $80{ }^{\circ} \mathrm{C}$ for two $\mathrm{h}$. Equation (2) shows the formation process of pure $\mathrm{MnO}_{2}$ [58]:

$$
2 \mathrm{KMnO}_{4}+3 \mathrm{MnSO}_{4}+2 \mathrm{H}_{2} \mathrm{O} \rightarrow 5 \mathrm{MnO}_{2}+2 \mathrm{H}_{2} \mathrm{SO}_{4}+\mathrm{K}_{2} \mathrm{SO}_{4}
$$

Then, $0.01 \mathrm{~g}$ of the prepared $\mathrm{MnO}_{2}$ was mixed with $0.1 \mathrm{~g}$ of graphite powder and $20 \mathrm{~mL}$ of deionized water in an ultrasound bath for $30 \mathrm{~min}$. The synthesis of $\mathrm{MnO}_{2} / \mathrm{C}$ was carried out under the same conditions as for the sample S1.

The prepared nanocomposites' morphology, structure and composition were characterized using an SEM-focused ion beam facility (Helios Nanolab 650, FEI, Eindhoven, The Netherlands) equipped with an EDX spectrometer (INCA Energy 350 X-Max 20, Oxford Instruments, Oxford, UK). The amount of active material was determined using an ICP optical emission spectrometer Optima700DV (Perkin Elmer, Waltham, MA, USA).

The shape and size of catalyst particles were examined using a Transmission Electron Microscope Tecnai G2 F20 X-TWIN (FEI, Eindhoven, The Netherlands) equipped with an EDAX spectrometer with an r-TEM detector. For microscopic examinations, $10 \mathrm{mg}$ of sample was first sonicated in $1 \mathrm{~mL}$ of ethanol for $1 \mathrm{~h}$ and then deposited on the $\mathrm{Cu}$ grid covered with a continuous carbon film.

XPS measurements were carried out to obtain information about the elemental chemical states and surface composition of powders on the upgraded Vacuum Generator (VG) ESCALAB MKII spectrometer (VG Scientific, UK) fitted with a new XR4 twin anode. The non-monochromatized $\mathrm{Al} \mathrm{K} \alpha \mathrm{X}$-ray source was operated at $\mathrm{h} v=1486.6 \mathrm{eV}$ with $300 \mathrm{~W}$ power $(20 \mathrm{~mA} / 15 \mathrm{kV})$, and the pressure in the analysis chamber was lower than $5 \times 10^{-7} \mathrm{~Pa}$ during spectral acquisition. The analyzer work function was determined, assuming the binding energy of the Au4f7/2 peak to be $84.0 \mathrm{eV}$. The spectra were acquired with an electron analyzer pass energy of $20 \mathrm{eV}$ for narrow scans and resolution of $0.05 \mathrm{eV}$ and with a pass energy of $100 \mathrm{eV}$ for survey spectra. All spectra were recorded at a $90^{\circ}$ take-off angle. The spectra calibration, processing, and fitting routines were done using Avantage software (v5.962) provided by Thermo VG Scientific (Waltham, MA, USA). Core level peaks of Mn 2p, Mn 3s, O 1s, and C 1s were recorded and analyzed using a nonlinear Shirley-type background. The calculation of the elemental composition was performed on the basis of Scofield's relative sensitivity factors.

XRD patterns of studied powders were measured using an X-ray diffractometer SmartLab (Rigaku, Japan) equipped with a $9 \mathrm{~kW}$ rotating $\mathrm{Cu}$ anode $\mathrm{X}$-ray tube. The measurements were performed using Bragg-Brentano geometry with a graphite monochromator on the diffracted beam and a step scan mode with the step size of $0.02^{\circ}$ (in $2 \theta$ scale) and counting time of 1 s per step. The measurements were conducted in the $2 \theta$ range $10-75^{\circ}$. Phase identification was performed using software package PDXL (Rigaku, Japan) and ICDD powder diffraction database PDF-4+ (2020 release).

All electrochemical measurements were performed with a three-electrode cell using cyclic voltammetry $(\mathrm{CV})$ and galvanostatic charge/discharge (GCD). The prepared $\mathrm{MnO}_{2} / \mathrm{C}$ nanocomposites coated on the glassy carbon electrode (GCE) were employed as the working electrode; a Pt sheet as a counter electrode and an $\mathrm{Ag} / \mathrm{AgCl} / \mathrm{KCl}$ electrode were used as a reference. The working electrodes were prepared as follows: the required amount of the active material $\left(\mathrm{MnO}_{2} / \mathrm{C}\right)$ was dispersed ultrasonically in $2 \%$ of PVDF in an NMP solution for $1 \mathrm{~h}$. Then, the obtained slurry was pipetted onto the polished surface of GCE and dried in an oven at a temperature of $80^{\circ} \mathrm{C}$ for $2 \mathrm{~h}$.

All electrochemical measurements were performed with a Zennium electrochemical workstation (ZAHNER-Elektrik GmbH \& Co.KG, Kronach, Germany). Cyclic voltammograms (CVs) were recorded in a $1 \mathrm{M} \mathrm{Na}_{2} \mathrm{SO}_{4}$ solution at different scan rates between 10 and $200 \mathrm{mV} \mathrm{s}^{-1}$. All solutions were de-aerated by argon for $15 \mathrm{~min}$ before measurements. 
The specific capacitance $\mathrm{Cs}\left(\mathrm{F} \mathrm{g}^{-1}\right)$ of the electrode material was calculated from the $\mathrm{CV}$ test according to the following equation (Equation (3)) [43]:

$$
C s=\frac{1}{m \cdot v \cdot \Delta V} \int i d v,
$$

where $C_{s}$, is the specific capacitance $\left(\mathrm{F} \mathrm{g} \mathrm{g}^{-1}\right), m$-the mass of the active material $(\mathrm{g}), v$ - the scan rate of potential $\left(\mathrm{V} \mathrm{s}^{-1}\right), \Delta V$ - the range of scan potential $(\mathrm{V})$, and $i$ - the current $(\mathrm{A})$.

Further, galvanostatic charge/discharge cycling was carried out within a potential range between 0 and $1 \mathrm{~V}$ at a current density of $1,2,5,10$, and $20 \mathrm{~A} \mathrm{~g}^{-1}$. The $C_{s}$ was calculated using the following equation (Equation (4)) [55]:

$$
C s=\frac{\mathrm{I} \Delta t}{m \cdot \Delta V}
$$

where $I$ is the discharge current (A), $\Delta t$ is the time for a full discharge (s), and $\Delta V$ represents the voltage change during the discharge process $(\mathrm{V})$.

\section{Results}

The carbon-supported $\mathrm{MnO}_{2}$ nanocomposites were prepared using the microwaveassisted heating method and two different approaches. The $\mathrm{MnO}_{2} / \mathrm{C}$ nanocomposite, labeled as sample $\mathrm{S} 1$, was prepared directly by the microwave-assisted synthesis of mixed $\mathrm{KMnO}_{4}$ and carbon powder components. Another $\mathrm{MnO}_{2} / \mathrm{C}$ nanocomposite, labeled as sample S2, was prepared in another way: at first, pure $\mathrm{MnO}_{2}$ was obtained by synthesizing $\mathrm{KMnO}_{4}$ and $\mathrm{MnSO}_{4}$. Then, the mixture of the obtained $\mathrm{MnO}_{2}$ and carbon powder was affected by microwave-assisted heating.

SEM images of the prepared $\mathrm{MnO}_{2} / \mathrm{C}$ samples $\mathrm{S} 1(\mathrm{a}, \mathrm{b})$ and $\mathrm{S} 2(\mathrm{c}, \mathrm{d})$ under different magnifications are presented in Figure 1.

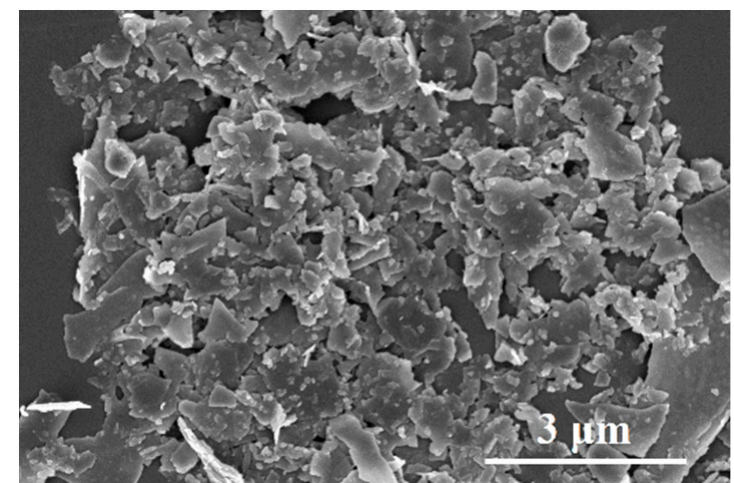

(a)

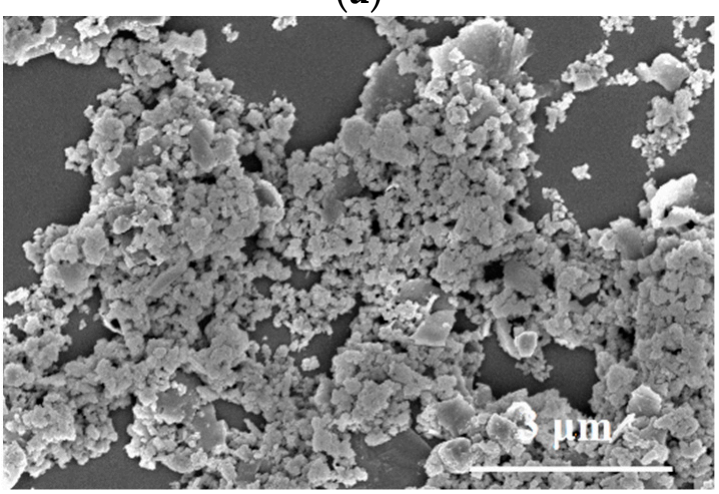

(c)

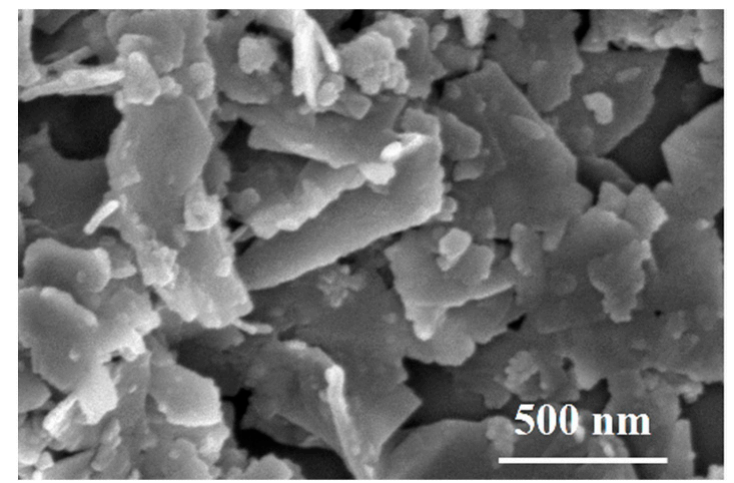

(b)

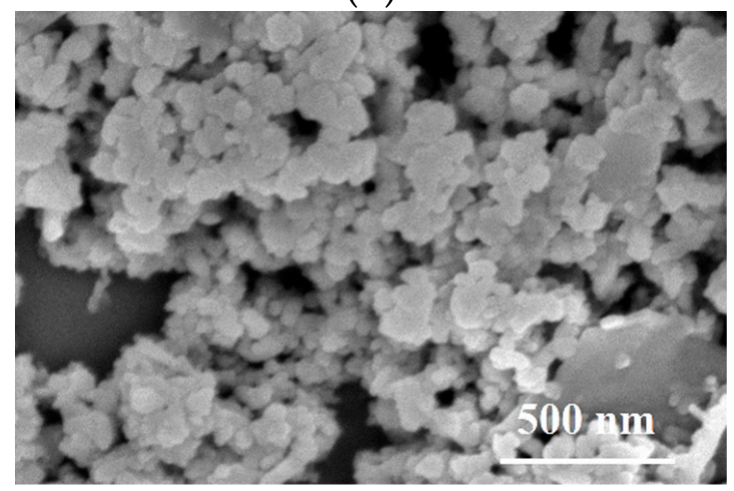

(d)

Figure 1. SEM images of $\mathrm{MnO}_{2} / \mathrm{C}:(\mathbf{a}, \mathbf{b})$ sample $\mathrm{S} 1 ;(\mathbf{c}, \mathbf{d})$ sample S2 under different magnifications. 
As evident, both samples are composed of spherical manganese nanograins located on the carbon surface, but they differ significantly in particle number, size and density. In the case of sample $\mathrm{S1}$, a sparse population of almost separate particles under a low $\mathrm{MnO}_{2}$ aggregation level is arranged (Figure 1a,b). The size of particles in this sample is close to $20 \mathrm{~nm}$. In the case of sample S2, a nanograins' aggregate forms a large porous network structure with carbon embedded inside (Figure 1c,d). The aggregation level of $\mathrm{MnO}_{2}$ develops to a large extent without any clear interparticle boundaries.

The samples $\mathrm{S} 1$ and $\mathrm{S} 2$ were further characterized by TEM analysis. TEM images of the samples S1 and S2 confirm the fibrous morphologies of both samples with the more expressed one for sample S2 (Figure 2). It was found that in the prepared sample S1, the $\mathrm{MnO}_{2}$ nanoparticles are spherical and are ca. $13-18 \mathrm{~nm}$ in size (Figure 2a,b). Furthermore, no large $\mathrm{MnO}_{2}$ nanoparticles are present within the prepared sample, indicating their negligible aggregation. In the case of sample $\mathrm{S} 2$, thin flakelike morphology is observed (Figure 2c,d).

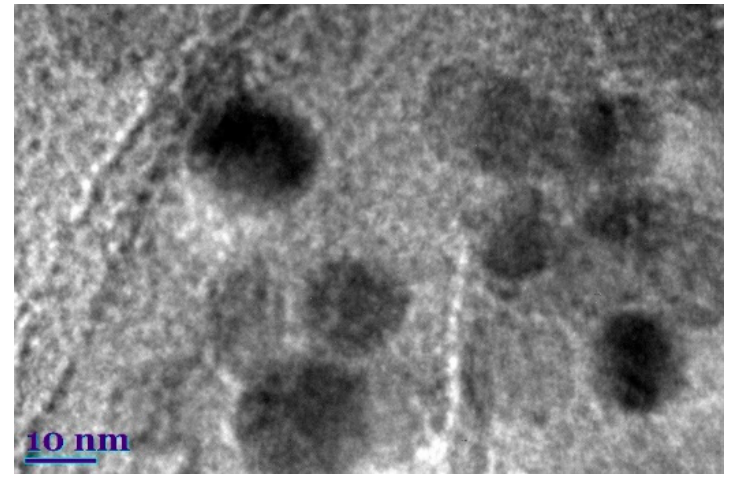

(a)

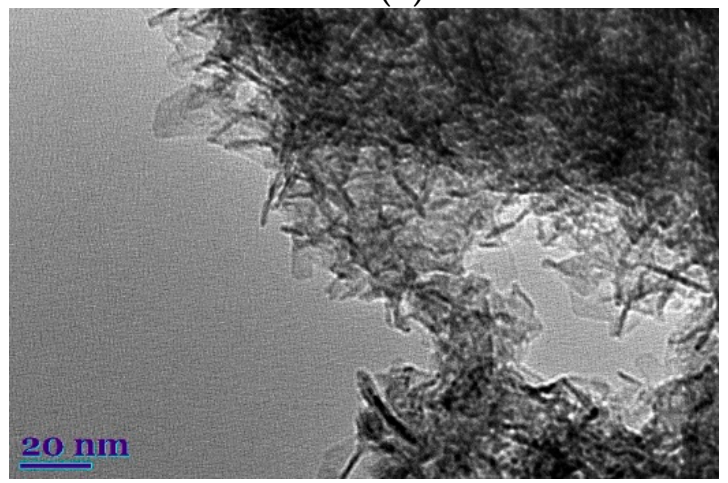

(c)

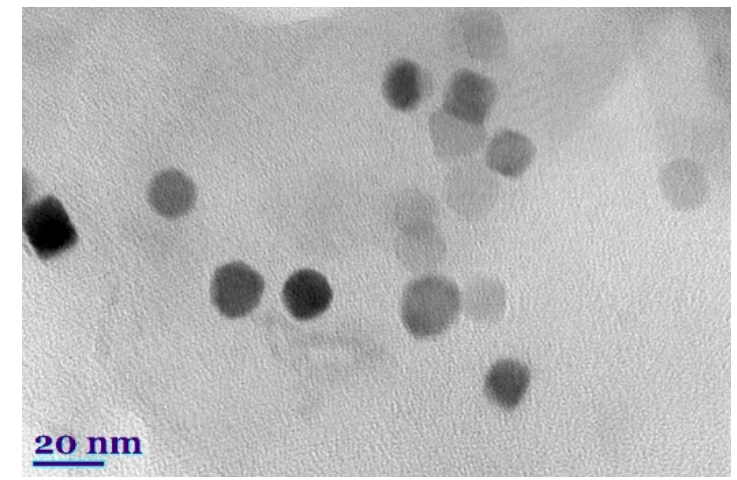

(b)

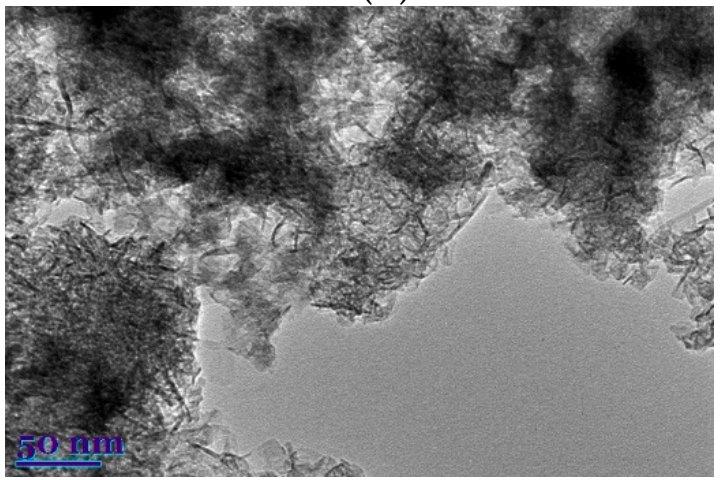

(d)

Figure 2. TEM images of $\mathrm{MnO}_{2} / \mathrm{C}:(\mathbf{a}, \mathbf{b})$ sample $\mathrm{S} 1$; (c,d) sample $\mathrm{S} 2$ under different magnifications.

The chemical composition and the surface electronic state of the prepared $\mathrm{MnO}_{2} / \mathrm{C}$ nanocomposites were analyzed using XPS. The $\mathrm{C} 1$ s signal and Mn 2p and $\mathrm{O} 1 \mathrm{~s}$ peaks were observed in the XPS survey spectra of both samples S1 and S2 (Figure 3a). It indicates the successful synthesis of $\mathrm{MnO}_{2} / \mathrm{C}$, while $\mathrm{K}$ content in the samples S1 and S2 was ca. 3.5 and 0.88 at.\%, respectively. In both cases, the deconvoluted spectra of Mn show a spin-orbit doublet of the main Mn 2p3/2 and Mn 2p1/2 peaks located at binding energies $\left(E_{\mathrm{b}}\right)$ of $642.2 \mathrm{eV}$ and $654.0 \mathrm{eV}$, respectively, with a spin-energy separation of $11.8 \mathrm{eV}$ (not shown). This value confirms the presence of $\mathrm{MnO}_{2}$ in the prepared nanocomposites [59-62]. 


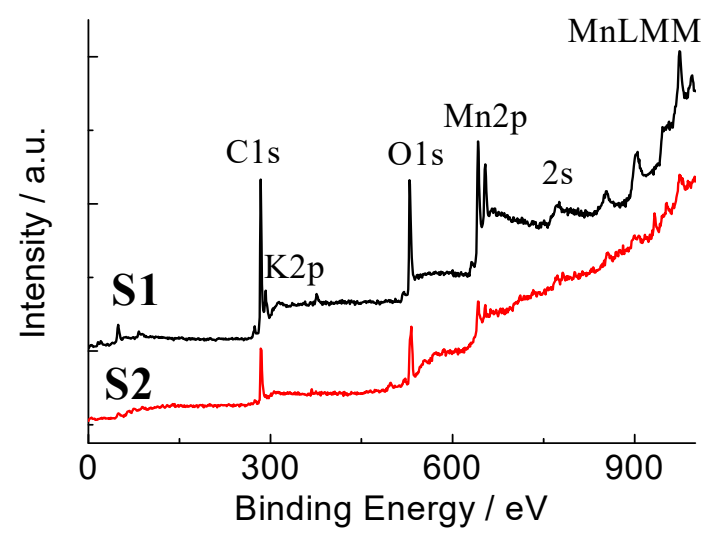

(a)

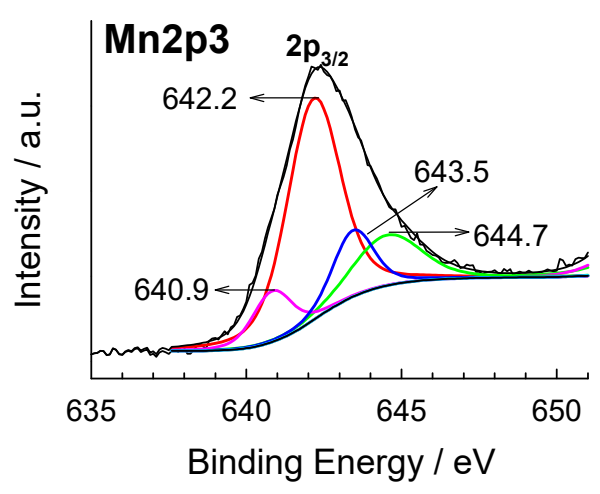

(b)

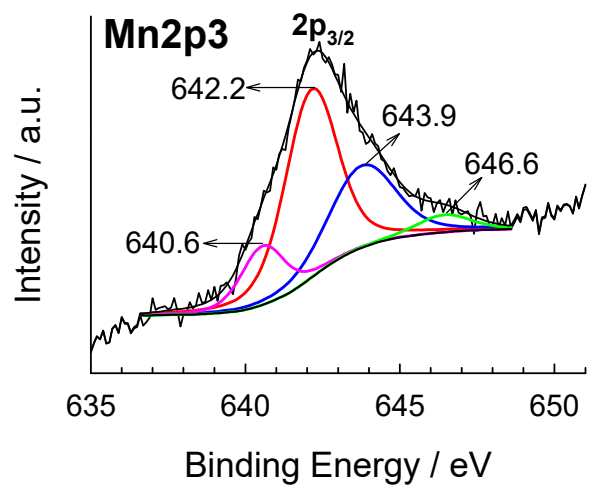

(d)

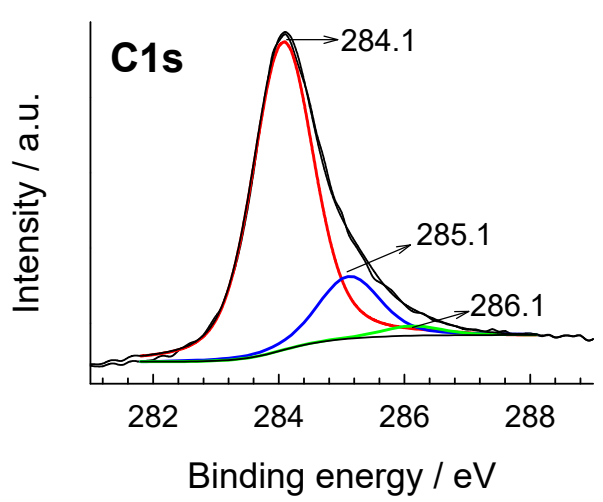

(c)

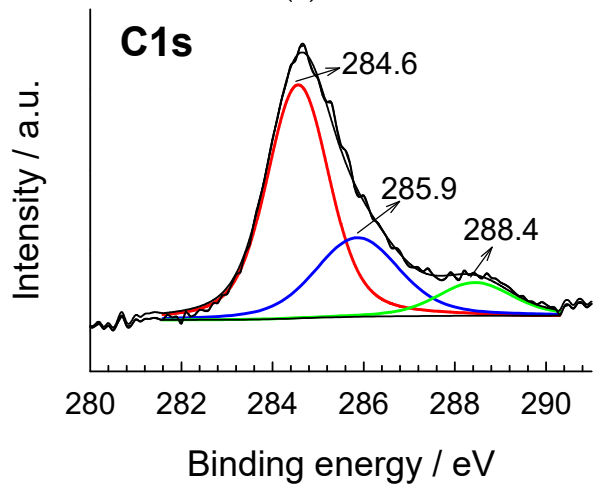

(e)

Figure 3. Survey spectra for samples S1 and S2 (a). XPS spectra of Mn 2p and C 1s for $\mathrm{MnO}_{2} / \mathrm{C}:(\mathbf{b}, \mathbf{c})$ sample S1; (d,e) sample S2.

XPS spectra of Mn2p3/2 and $\mathrm{C} 1 \mathrm{~s}$ for $\mathrm{MnO}_{2} / \mathrm{C}$ samples $\mathrm{S} 1$ and $\mathrm{S} 2$ are shown in Figure $3 b-$ e. As evident, for both samples, the Mn 2p3/2 peaks were deconvoluted into four peaks at binding energies of $640.6 \pm 0.3,642.2,643.5$, and 644.7 and $646.6 \mathrm{eV}$, indicating the mixed-valence of manganese oxide phases (Figure $3 b, c$ ). Following the data reported in [59-64], the position of deconvoluted Mn 2p3/2 peaks are generally assigned to $\mathrm{Mn}(\mathrm{IV})$ or $\mathrm{Mn}$ (II) oxidation state at $E_{\mathrm{b}}$ ranging between $641.85-643.0 \mathrm{eV}$ or $640.10-641.12 \mathrm{eV}$, respectively. Therefore, peaks determined at $640.6 \pm 0.3$ and $642.2 \mathrm{eV}$ confirm the presence of $\mathrm{Mn}(\mathrm{II})$ and $\mathrm{Mn}(\mathrm{IV})$ species in the samples S1 and S2 (Figure 3b,c). Moreover, the additional peak at $644.7 \mathrm{eV}$ close to that obtained at $644.9 \mathrm{eV}$ in $[65,66]$ could similarly be assigned to a satellite shake-up peak located at higher Eb values than the main component and is a characteristic feature of the $\mathrm{MnO}$ phase $\mathrm{Mn} 2 \mathrm{p}$ core peak maximum at $640.6 \pm 0.3 \mathrm{eV}$ [67]. Meanwhile, peaks at $643.5 \mathrm{eV}$ and $644.7 \mathrm{eV}$ based on data in [66] could be related to Mn (VI and VII) species in the samples. There is no Mn 2p3/2 signal 
$(647 \mathrm{eV})$ from permanganate ions, suggesting permanganate ions have been reduced to $\mathrm{MnO}_{2}$ [68]. It should be noted that the dominating fraction in the prepared samples S1 and S2 is the $\mathrm{MnO}_{2}$ phase and is equal to 59 and $53 \%$, respectively. At the same time, the $\mathrm{MnO}$ (Mn (II)) phase remains significantly lower compared to that determined for the $\mathrm{MnO}_{2}(\mathrm{Mn}(\mathrm{IV}))$ phase.

The high-resolution C 1s spectrum for sample S1 can be deconvoluted into three peaks centered at $E_{\mathrm{b}}$ of 284.1, 285.1 and $286.1 \mathrm{eV}$ (Figure 3d). The first one value could be assigned to carbon atoms $C-C$; meanwhile, other peaks could be assigned to oxygen functionalized carbon atoms, such as $\mathrm{C}-\mathrm{O}$, or $\mathrm{C}-\mathrm{OH}$ and $\mathrm{C}=\mathrm{O}[60,69]$.

In the case of the sample $S 2$, the $C 1$ s XPS spectrum could be fitted into three peaks at 284.6, 285.8, and $288.4 \mathrm{eV}$ (Figure $3 \mathrm{e}$ ), which corresponded to $\mathrm{C}-\mathrm{C} / \mathrm{C}=\mathrm{C}, \mathrm{C}-\mathrm{O}$, and $\mathrm{O}-\mathrm{C}=\mathrm{O}$ bonds, respectively [70]. The strong peak of $\mathrm{C}-\mathrm{C} / \mathrm{C}=\mathrm{C}$ bonds shows that carbon contained high graphitization.

The obtained XRD patterns for both $\mathrm{MnO}_{2} / \mathrm{C}$ samples are shown in Figure 4. The presence of broad peaks implied that the synthesized samples S1 and S2 are essentially a mixture of amorphous and nanocrystalline phases. The prominent peaks from both samples (Figure 4) locate at $26^{\circ}$, which can be assigned to the (002) crystal plane of graphitic carbon (ICDD card no. 00-056-0159). The diffraction peaks of $\alpha-\mathrm{MnO}_{2}$ are indexed according to ICDD card no. 04-005-4884, indicating a tetragonal unit cell with lattice parameters of $\mathrm{a}=\mathrm{b}=9.82 \AA$ and $\mathrm{c}=2.85 \AA$. The synthesized powders are composed of small crystallites with an average size of about $3.2 \pm 0.3 \mathrm{~nm}$.

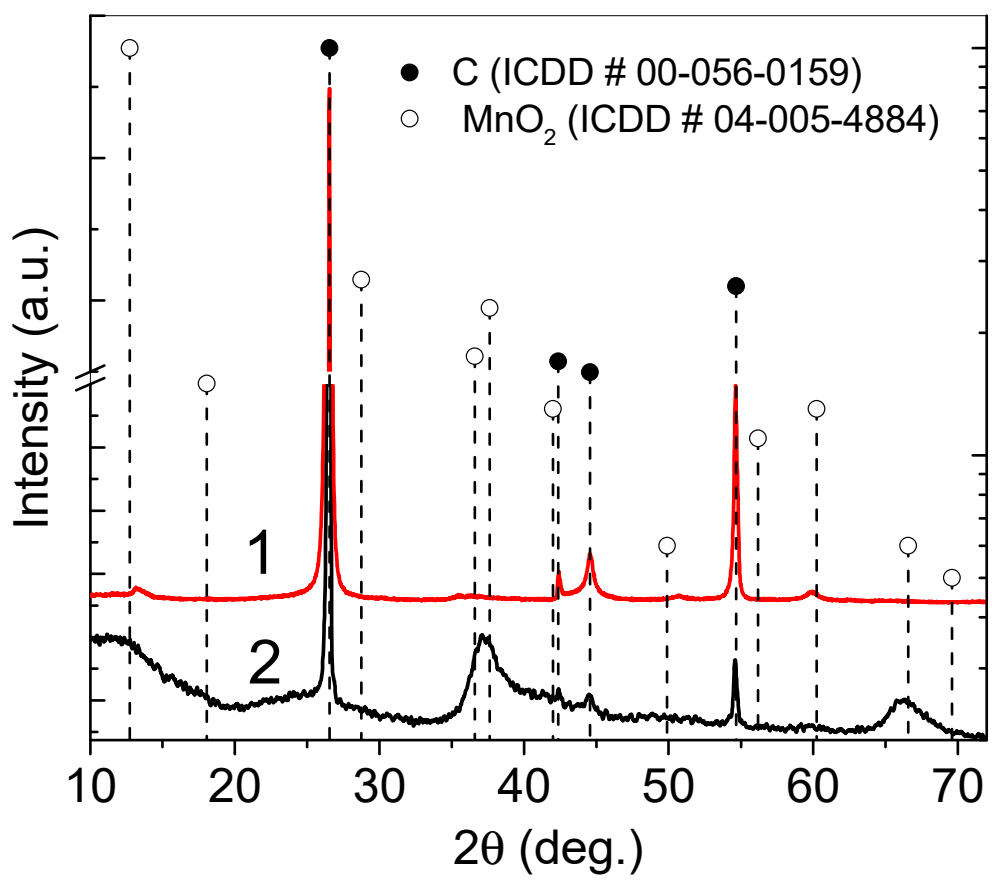

Figure 4. XRD patterns of samples S1 (1 pattern) and sample S2 (2 pattern).

The electrochemical performance of samples S1 and S2 was evaluated from the cyclic voltammetry and galvanostatic charge/discharge measurements using a three-electrode system in a $1 \mathrm{M} \mathrm{Na}_{2} \mathrm{SO}_{4}$ solution. Figure 5 shows the CV curves of the sample S1 (a), sample S2 (b), and pure carbon (c) at the scan rates of 10, 50, 100, and $200 \mathrm{mV} \mathrm{s}^{-1}$. No obvious peaks are observed in all the CV curves. This indicates that the electrodes are charged and discharge at a constant rate over the complete cycle. 


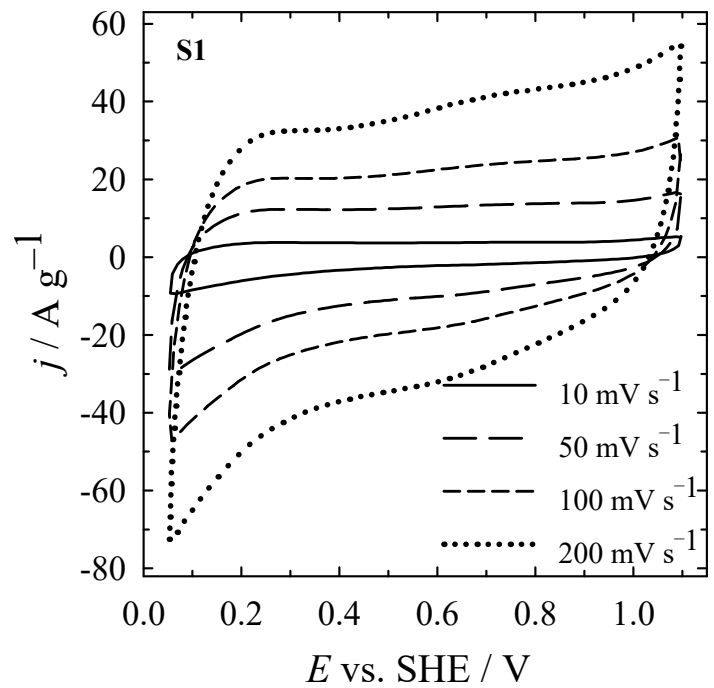

(a)

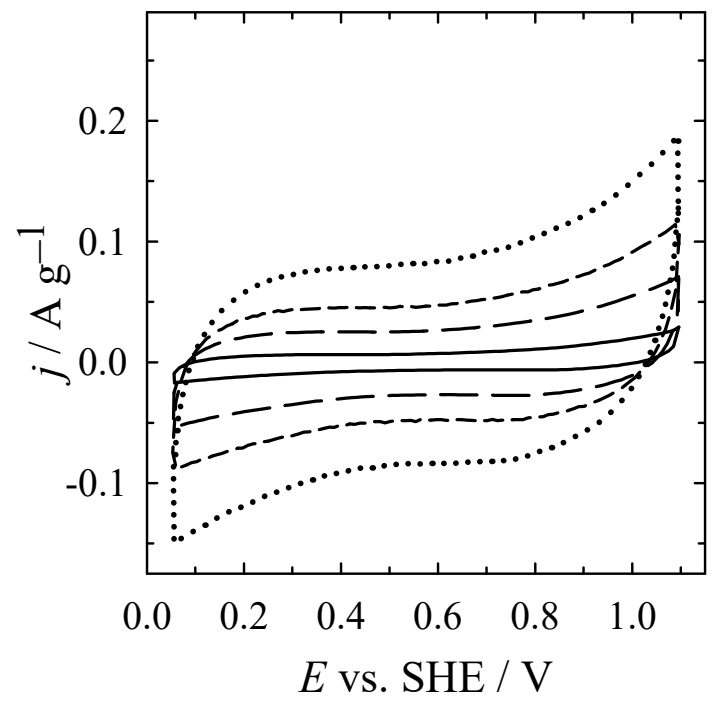

(c)

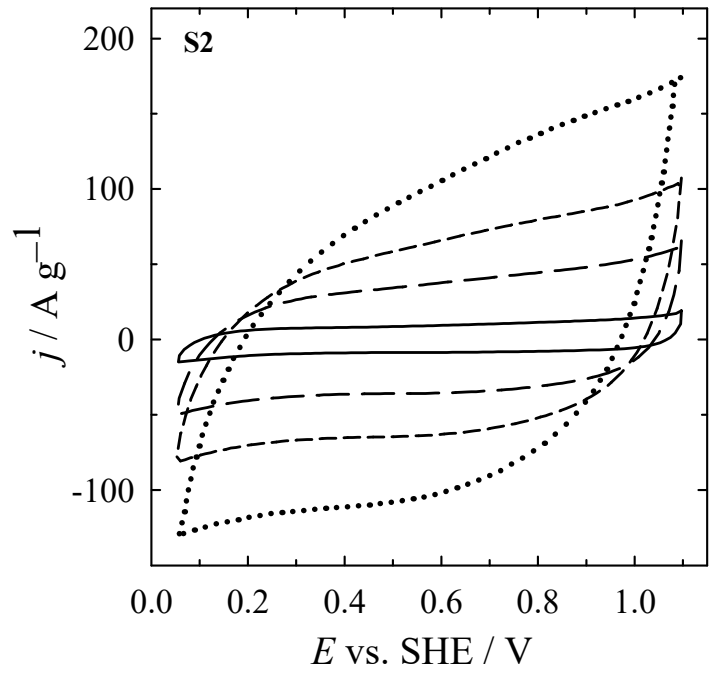

(b)

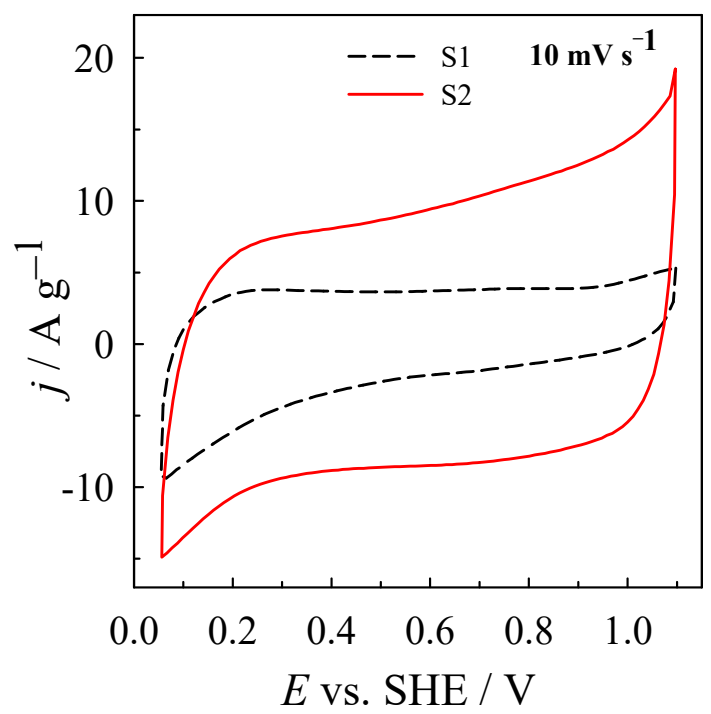

(d)

Figure 5. CVs of: (a) sample S1; (b) sample S2; (c) carbon were recorded in $1 \mathrm{M} \mathrm{Na}_{2} \mathrm{SO}_{4}$ at different scan rates. (d) CVs of samples $\mathrm{S} 1$ and $\mathrm{S} 2$ at $10 \mathrm{mV} \mathrm{s}^{-1}$.

Both sample S1 and carbon show symmetrical rectangular shapes, which indicates the ideal capacitive behavior of those samples (Figure 5a,c). In the case of sample S2, deviations in the rectangularity of CV curves occur (Figure 5b). It can be seen that the current response of sample S2 is significantly higher as compared with that of sample S1 and carbon (Figure $5 \mathrm{a}-\mathrm{c}$ ). It is clearly seen that the sample S2 shows a significantly higher capacitive behavior as compared with that of sample S1 (Figure $5 \mathrm{~d}$ ).

The calculated $\mathrm{C}_{\mathrm{S}}$ values for the sample $\mathrm{S} 2$ were $980.7,743.2,641.0$, and $536.6 \mathrm{~F} \mathrm{~g}^{-1}$ at scan rates of 10,50,100, and $200 \mathrm{mV} \mathrm{s}^{-1}$, respectively (Figure 6). Meanwhile, for the sample S1, Cs values were 535.8, 349.6, 275.2, and 209.7 $\mathrm{F} \mathrm{g}^{-1}$ at scan rates of 10, 50, 100, and $200 \mathrm{mV} \mathrm{s}^{-1}$. Those values were found to be ca. 1.8-2.6 times lower than those obtained for sample S2. 


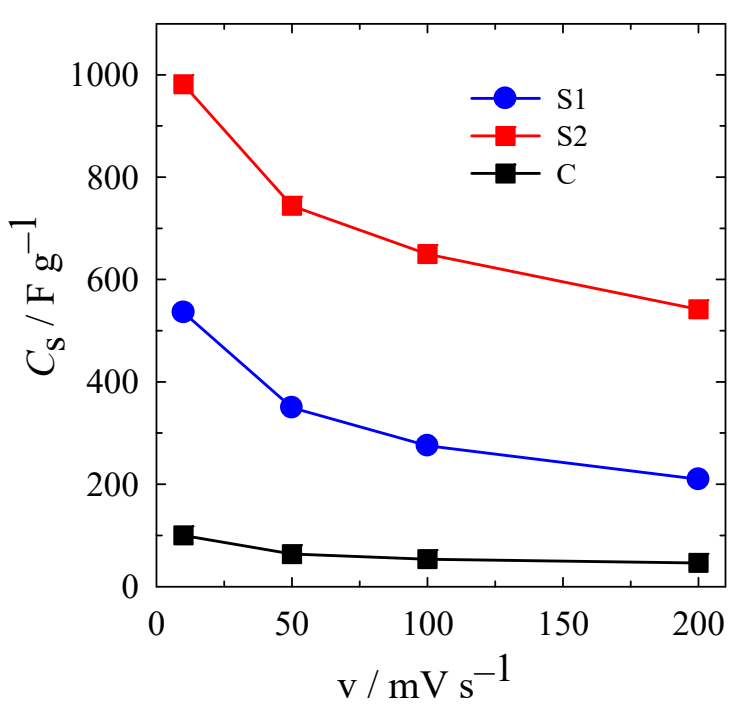

Figure 6. Specific capacitances of the sample S1, sample S2, and carbon obtained from CV curves.

Comparisons of the supercapacitive behavior of various $\mathrm{MnO}_{2}$-based electrode materials reported in the literature and the present work are listed in Table 1, exhibiting the high specific capacitance of our prepared electrode materials.

Table 1. Comparisons of specific capacitance for various $\mathrm{MnO}_{2}$-based electrode materials.

\begin{tabular}{|c|c|c|c|}
\hline Materials & $\begin{array}{l}\text { Scan Rate, } \\
\mathrm{mV} \mathrm{s}^{-1}\end{array}$ & $\begin{array}{c}\text { Specific } \\
\text { Capacitance, } \\
\text { F g }^{-1}\end{array}$ & Ref. \\
\hline $\mathrm{MnO}_{2} / \mathrm{C}(\mathrm{S} 2)$ & 10 & 980.7 & This work \\
\hline $\mathrm{MnO}_{2} / \mathrm{C}(\mathrm{S} 1)$ & 10 & 535.8 & This work \\
\hline Self-branched & & & \\
\hline $\begin{array}{l}\alpha-\mathrm{MnO}_{2} / \delta-\mathrm{MnO}_{2} \\
\text { heterojunction } \\
\text { nanowires }\end{array}$ & 10 & 152.0 & [22] \\
\hline $\mathrm{MnO}_{2}$ & 5 & 380.0 & [24] \\
\hline $\mathrm{MnO}_{2}$ & 10 & 154.0 & [29] \\
\hline $\mathrm{MnO}_{2} / 3 \mathrm{D}-\mathrm{PC}$ & 1 & 416.0 & [47] \\
\hline $\mathrm{MnO}_{2}$ & 5 & 547.0 & [68] \\
\hline $\begin{array}{l}\text { Ultra-long } \mathrm{MnO}_{2} \\
\text { nanowires }\end{array}$ & 2 & 495.0 & [69] \\
\hline $\mathrm{MnO}_{2} \mathrm{NPs} / \mathrm{Ni}$ foam & 5 & 549.0 & [71] \\
\hline $\mathrm{MnO}_{2} / \mathrm{MWCNT}$ & 2 & 553.0 & [72] \\
\hline
\end{tabular}

Galvanostatic charge/discharge curves for the sample S2 measured at different current densities of 1, 2, 5, 10, and $20 \mathrm{~A} \mathrm{~g} \mathrm{~g}^{-1}$ are shown in Figure 7a. The shapes of the curves show a typical triangular symmetrical distribution with a slight curvature. This result indicates a combination of electric double-layer and pseudocapacitive contributions. Specific capacitance values were calculated from the discharge test. It was found that the sample S2 can deliver high Cs values of 949.3, 719.3, 480.8, 406.7, and $371.5 \mathrm{~F} \mathrm{~g}^{-1}$ at a current density of 1, 2, 5, 10, and $20 \mathrm{~A} \mathrm{~g}^{-1}$ (Figure $7 \mathrm{~b}$ ). The long-term stability of the charge/discharge process was also performed on this sample S2 at a high current density of $20 \mathrm{~A} \mathrm{~g}^{-1}$ up to 100 cycles (Figure 7c). As evident, this electrode showed excellent long-term stability with $93 \%$ retention of its initial capacitance value during 100 cycles. 

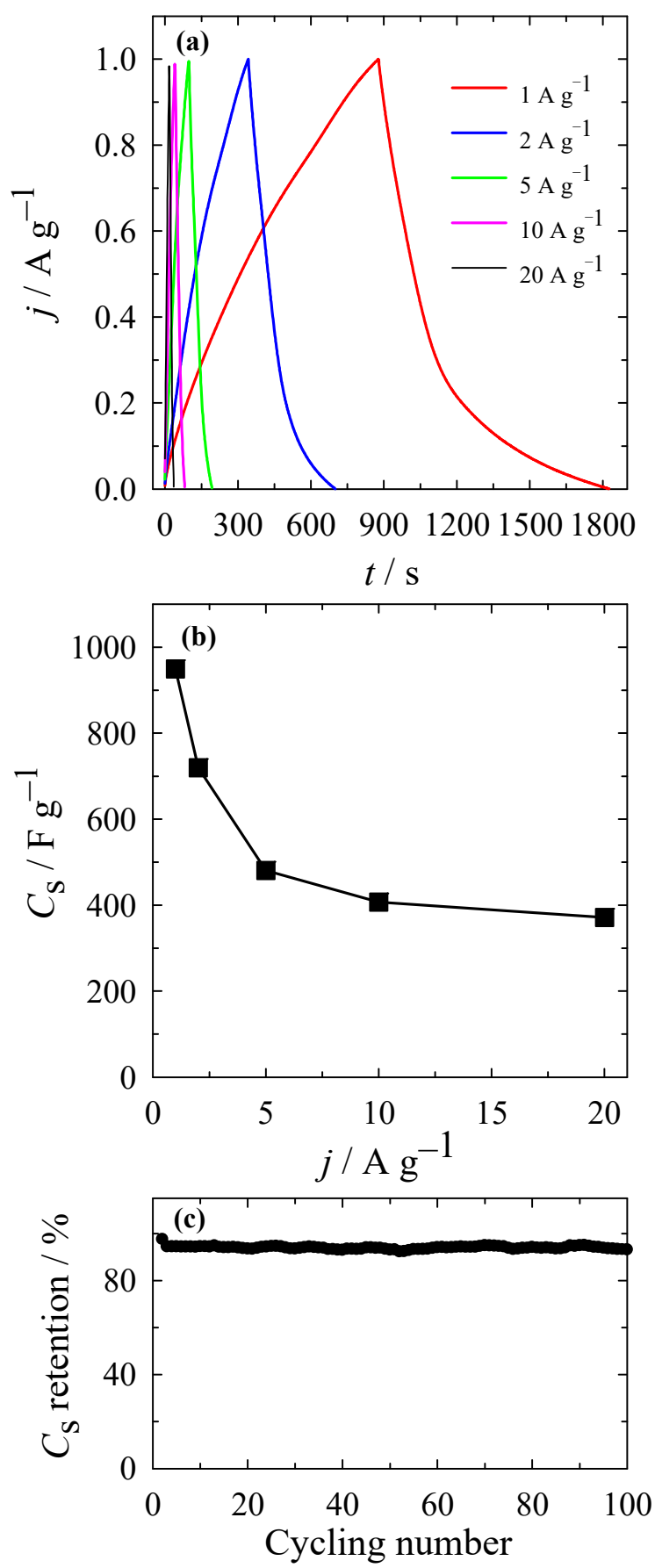

Figure 7. (a) Galvanostatic charge/discharge curves of the sample S2 measured at different constant current densities of 1-20 A g ${ }^{-1}$; (b) Specific capacitance obtained from galvanostatic charge/discharge curves with different current densities.

\section{Conclusions}

We have successfully fabricated carbon-supported $\mathrm{MnO}_{2}$ nanocomposites via a simple microwave-assisted heating method. Different architecture containing $\mathrm{MnO}_{2}$ nanocomposites demonstrates improved conductivity, which is a key limitation in pseudocapacitors. The electrochemical measurements revealed that (due to this conductivity) $\mathrm{MnO}_{2} / \mathrm{C}$ nanocomposites, especially those prepared via a two-step procedure, exhibit excellent electrochemical performance, including a high specific capacitance of $980.7 \mathrm{~F} \mathrm{~g}^{-1}$. Moreover, the specific capacitance retention was $93 \%$ after 100 cycles at $20 \mathrm{~A} \mathrm{~g}^{-1}$, indicating good electrochemical stability. The obtained results demonstrate that the prepared $\mathrm{MnO}_{2} / \mathrm{C}$ 
nanocomposites should be a promising electrode material for supercapacitor applications and could be further extended to fabricate other materials for supercapacitors.

Author Contributions: This study was conducted through the contributions of all authors. Conceptualization, J.J.; L.T.-T. and E.N.; methodology, G.S., A.D., V.P. and V.J.; investigation, J.V., G.S. and A.D.; writing-original draft preparation, J.J. and D.S.; writing—review and editing, L.T.-T. and E.N.; visualization, D.S., J.V., V.P. and V.J. All authors have read and agreed to the published version of the manuscript.

Funding: This research was funded by the European Social Fund under the No 09.3.3-LMT-K-712-020142 “Development of Competencies of Scientists, other Researchers, and Students through Practical Research Activities" measure.

Institutional Review Board Statement: Not applicable.

Informed Consent Statement: Not applicable.

Conflicts of Interest: The authors declare no conflict of interest.

\section{References}

1. Gopi, C.V.M.; Vinodh, R.; Sambasivam, S.; Obaidat, I.M.; Kim, H.-J. Recent progress of advanced energy storage materials for flexible and wearable supercapacitor: From design and development to applications. J. Energy Storage 2020, 27, 101035. [CrossRef]

2. Poonam; Sharma, K.; Arora, A.; Tripathi, S.K. Review of supercapacitors: Materials and devices. J. Energy Storage 2019, 21, 801-825. [CrossRef]

3. Liu, C.; Li, F.; Ma, L.-P.; Cheng, H.-M. Advanced Materials for Energy Storage. Adv. Mater. 2010, 22, E28-E62. [CrossRef] [PubMed]

4. Miller, E.E.; Hua, Y.; Tezel, F.H. Materials for energy storage: Review of electrode materials and methods of increasing capacitance for supercapacitors. J. Energy Storage 2018, 20, 30-40. [CrossRef]

5. Wang, F.; Wu, X.; Yuan, X.; Liu, Z.; Zhang, Y.; Fu, L.; Zhu, Y.; Zhou, Q.; Wu, Y.; Huang, W. Latest advances in supercapacitors: From new electrode materials to novel device designs. Chem. Soc. Rev. 2017, 46, 6816-6854. [CrossRef] [PubMed]

6. Liu, C.; Yan, X.; Hu, F.; Gao, G.; Wu, G.; Yang, X. Toward Superior Capacitive Energy Storage: Recent Advances in Pore Engineering for Dense Electrodes. Adv. Mater. 2018, 30, e1705713. [CrossRef] [PubMed]

7. Simon, P.; Gogotsi, Y. Materials for electrochemical capacitors. Nat. Mater. 2008, 7, 845-854. [CrossRef]

8. Guo, W.; Yu, C.; Li, S.; Wang, Z.; Yu, J.; Huang, H.; Qiu, J. Strategies and insights towards the intrinsic capacitive properties of $\mathrm{MnO}_{2}$ for supercapacitors: Challenges and perspectives. Nano Energy 2019, 57, 459-472. [CrossRef]

9. Wang, G.; Zhang, L.; Zhang, J. A review of electrode materials for electrochemical supercapacitors. Chem. Soc. Rev. 2012, 41, 797-828. [CrossRef]

10. Muzaffar, A.; Ahamed, M.B.; Deshmukh, K.; Thirumalai, J. A review on recent advances in hybrid supercapacitors: Design, fabrication and applications. Renew. Sustain. Energy Rev. 2019, 101, 123-145. [CrossRef]

11. Afif, A.; Rahman, S.M.; Azad, A.T.; Zaini, J.; Islam, A.; Azad, A. Advanced materials and technologies for hybrid supercapacitors for energy storage-A review. J. Energy Storage 2019, 25, 100852. [CrossRef]

12. Xu, W.; Jiang, Z.; Yang, Q.; Huo, W.; Javed, M.S.; Li, Y.; Huang, L.; Gu, X.; Hu, C. Approaching the lithium-manganese oxides' energy storage limit with $\mathrm{Li}_{2} \mathrm{MnO}_{3}$ nanorods for high-performance supercapacitor. Nano Energy 2018, 43, 168-176. [CrossRef]

13. Xia, H.; Hong, C.; Li, B.; Zhao, B.; Lin, Z.; Zheng, M.; Savilov, S.V.; Aldoshin, S.M. Facile Synthesis of Hematite QuantumDot/Functionalized Graphene-Sheet Composites as Advanced Anode Materials for Asymmetric Supercapacitors. Adv. Funct. Mater. 2015, 25, 627-635. [CrossRef]

14. Qiu, T.; Luo, B.; Giersig, M.; Akinoglu, E.M.; Hao, L.; Wang, X.; Shi, L.; Jin, M.; Zhi, L. Au@MnO 2 Core-Shell Nanomesh Electrodes for Transparent Flexible Supercapacitors. Small 2014, 10, 4136-4141. [CrossRef]

15. Huang, M.; Zhang, Y.; Li, F.; Zhang, L.; Wen, Z.; Liu, Q. Facile synthesis of hierarchical $\mathrm{Co}_{3} \mathrm{O}_{4} @ \mathrm{MnO}_{2}$ core-shell arrays on Ni foam for asymmetric supercapacitors. J. Power Sources 2014, 252, 98-106. [CrossRef]

16. Radhamani, A.V.; Shareef, K.M.; Rao, M.S.R. ZnO@ $\mathrm{MnO}_{2}$ Core-Shell Nanofiber Cathodes for High Performance Asymmetric Supercapacitors. ACS Appl. Mater. Interfaces 2016, 8, 30531-30542. [CrossRef]

17. Wang, Y.; Zeng, J.; Li, J.; Cui, X.; Al-Enizi, A.M.; Zhang, L.; Zheng, G. One-dimensional nanostructures for flexible supercapacitors. J. Mater. Chem. A 2015, 3, 16382-16392. [CrossRef]

18. Liu, L.; Niu, Z.; Chen, J. Unconventional supercapacitors from nanocarbon-based electrode materials to device configurations. Chem. Soc. Rev. 2016, 45, 4340-4363. [CrossRef]

19. Huang, M.; Li, F.; Dong, F.; Zhang, Y.X.; Zhang, L. $\mathrm{MnO}_{2}$-based nanostructures for high-performance supercapacitors. J. Mater. Chem. A 2015, 3, 21380-21423. [CrossRef]

20. Huang, M.; Zhang, Y.; Li, F.; Zhang, L.; Ruoff, R.S.; Wen, Z.; Liu, Q. Self-Assembly of Mesoporous Nanotubes Assembled from Interwoven Ultrathin Birnessite-type $\mathrm{MnO}_{2}$ Nanosheets for Asymmetric Supercapacitors. Sci. Rep. 2015, 4, 3878. [CrossRef] 
21. Yin, B.; Zhang, S.; Jiao, Y.; Liu, Y.; Qu, F.; Wu, X. Facile synthesis of ultralong $\mathrm{MnO}_{2}$ nanowires as high performance supercapacitor electrodes and photocatalysts with enhanced photocatalytic activities. CrystEngComm 2014, 16, 9999-10005. [CrossRef]

22. Zhu, C.; Yang, L.; Seo, J.K.; Zhang, X.; Wang, S.; Shin, J.; Chao, D.; Zhang, H.; Meng, Y.S.; Fan, H.J. Self-branched $\alpha-\mathrm{MnO}_{2} / \delta-\mathrm{MnO}_{2}$ heterojunction nanowires with enhanced pseudocapacitance. Mater. Horiz. 2017, 4, 415-422. [CrossRef]

23. Lv, Q.; Sun, H.; Li, X.; Xiao, J.; Xiao, F.; Liu, L.; Luo, J.; Wang, S. Ultrahigh capacitive performance of three-dimensional electrode nanomaterials based on $\alpha-\mathrm{MnO}_{2}$ nanocrystallines induced by doping Au through $\AA$-scale channels. Nano Energy 2016, 21, 39-50. [CrossRef]

24. Kang, J.; Hirata, A.; Kang, L.; Zhang, X.; Hou, Y.; Chen, L.; Li, C.; Fujita, T.; Akagi, K.; Chen, M. Enhanced Supercapacitor Performance of $\mathrm{MnO}_{2}$ by Atomic Doping. Angew. Chem. Int. Ed. 2013, 52, 1664-1667. [CrossRef] [PubMed]

25. Hu, Z.; Xiao, X.; Chen, C.; Li, T.; Huang, L.; Zhang, C.; Su, J.; Miao, L.; Jiang, J.; Zhang, Y.; et al. Al-doped $\alpha-\mathrm{MnO}_{2}$ for high mass-loading pseudocapacitor with excellent cycling stability. Nano Energy 2015, 11, 226-234. [CrossRef]

26. Su, X.; Yu, L.; Cheng, G.; Zhang, H.; Sun, M.; Zhang, L.; Zhang, J. Controllable hydrothermal synthesis of Cu-doped $\delta$-MnO 2 films with different morphologies for energy storage and conversion using supercapacitors. Appl. Energy 2014, 134, 439-445. [CrossRef]

27. Peng, R.; Wu, N.; Zheng, Y.; Huang, Y.; Luo, Y.; Yu, P.; Zhuang, L. Large-Scale Synthesis of Metal-Ion-Doped Manganese Dioxide for Enhanced Electrochemical Performance. ACS Appl. Mater. Interfaces 2016, 8, 8474-8480. [CrossRef]

28. Wang, Z.; Wang, F.; Li, Y.; Hu, J.; Lu, Y.; Xu, M. Interlinked multiphase Fe-doped $\mathrm{MnO}_{2}$ nanostructures: A novel design for enhanced pseudocapacitive performance. Nanoscale 2016, 8, 7309-7317. [CrossRef]

29. Tang, C.-L.; Wei, X.; Jiang, Y.-M.; Wu, X.-Y.; Wang, K.-X.; Chen, J.-S.; Han, L.-N. Cobalt-Doped MnO 2 Hierarchical Yolk-Shell Spheres with Improved Supercapacitive Performance. J. Phys. Chem. C 2015, 119, 8465-8471. [CrossRef]

30. Hashem, A.M.A.; Abuzeid, H.M.; Narayanan, N.; Ehrenberg, H.; Julien, C. Synthesis, structure, magnetic, electrical and electrochemical properties of $\mathrm{Al}, \mathrm{Cu}$ and $\mathrm{Mg}$ doped $\mathrm{MnO}_{2}$. Mater. Chem. Phys. 2011, 130, 33-38. [CrossRef]

31. Zhang, X.; Meng, X.; Gong, S.; Li, P.; Jin, L.; Cao, Q. Synthesis and characterization of $3 \mathrm{D} \mathrm{MnO}_{2} /$ carbon microtube bundle for supercapacitor electrodes. Mater. Lett. 2016, 179, 73-77. [CrossRef]

32. Pandolfo, A.; Hollenkamp, A. Carbon properties and their role in supercapacitors. J. Power Sources 2006, 157, 11-27. [CrossRef]

33. Frackowiak, E. Carbon materials for supercapacitor application. Phys. Chem. Chem. Phys. 2007, 9, 1774-1785. [CrossRef] [PubMed]

34. Zhang, L.; Zhao, X.S. Carbon-based materials as supercapacitor electrodes. Chem. Soc. Rev. 2009, 38, 2520-2531. [CrossRef] [PubMed]

35. Vattikuti, S.P.; Reddy, B.P.; Byon, C.; Shim, J. Carbon/CuO nanosphere-anchored $\mathrm{g}-\mathrm{C}_{3} \mathrm{~N}_{4}$ nanosheets as ternary electrode material for supercapacitors. J. Solid State Chem. 2018, 262, 106-111. [CrossRef]

36. Vattikuti, S.V.P.; Police, A.K.R.; Shim, J.; Byon, C. Sacrificial-template-free synthesis of core-shell C@Bi $\mathrm{S}_{3}$ heterostructures for efficient supercapacitor and $\mathrm{H}_{2}$ production applications. Sci. Rep. 2018, 8, 4194. [CrossRef]

37. Vattikuti, S.P.; Devarayapalli, K.C.; Dang, N.N.; Shim, J. 1D/1D $\mathrm{Na}_{2} \mathrm{Ti}_{3} \mathrm{O}_{7} /$ SWCNTs electrode for split-cell-type asymmetric supercapacitor device. Ceram. Int. 2021, 47, 11602-11610. [CrossRef]

38. Ping, Y.; Liu, Z.; Li, J.; Han, J.; Yang, Y.; Xiong, B.; Fang, P.; He, C. Boosting the performance of supercapacitors based hierarchically porous carbon from natural Juncus effuses by incorporation of $\mathrm{MnO}_{2}$. J. Alloys Compd. 2019, 805, 822-830. [CrossRef]

39. Feng, D.-Y.; Sun, Z.; Huang, Z.-H.; Cai, X.; Song, Y.; Liu, X.-X. Highly loaded manganese oxide with high rate capability for capacitive applications. J. Power Sources 2018, 396, 238-245. [CrossRef]

40. Sun, L.; Li, N.; Zhang, S.; Yu, X.; Liu, C.; Zhou, Y.; Han, S.; Wang, W.; Wang, Z. Nitrogen-containing porous carbon/ $\alpha-\mathrm{MnO}_{2}$ nanowires composite electrode towards supercapacitor applications. J. Alloys Compd. 2019, 789, 910-918. [CrossRef]

41. Su, X.; Yu, L.; Cheng, G.; Zhang, H.; Sun, M.; Zhang, X. High-performance $\alpha-\mathrm{MnO}_{2}$ nanowire electrode for supercapacitors. Appl. Energy 2015, 153, 94-100. [CrossRef]

42. Lei, R.; Zhang, H.; Lei, W.; Li, D.; Fang, Q.; Ni, H.; Gu, H. $\mathrm{MnO}_{2}$ nanowires electrodeposited on freestanding graphenated carbon nanotubes as binder-free electrodes with enhanced supercapacitor performance. Mater. Lett. 2019, 249, 140-142. [CrossRef]

43. Meng, X.; Lu, L.; Sun, C. Green Synthesis of Three-Dimensional $\mathrm{MnO}_{2} /$ Graphene Hydrogel Composites as a High-Performance Electrode Material for Supercapacitors. ACS Appl. Mater. Interfaces 2018, 10, 16474-16481. [CrossRef] [PubMed]

44. Qiu, Y.; Xu, P.; Guo, B.; Cheng, Z.; Fan, H.; Yang, M.; Yang, X.; Li, J. Electrodeposition of manganese dioxide film on activated carbon paper and its application in supercapacitors with high rate capability. RSC Adv. 2014, 4, 64187-64192. [CrossRef]

45. Cheng, H.; Zhao, S.; Yi, F.; Gao, A.; Shu, D.; Ao, Z.; Huang, S.; Zhou, X.; He, C.; Li, S.; et al. Supramolecule-assisted synthesis of in-situ carbon-coated $\mathrm{MnO}_{2}$ nanosphere for supercapacitors. J. Alloys Compd. 2019, 779, 550-556. [CrossRef]

46. Yang, M.; Kim, D.S.; Hong, S.B.; Sim, J.-W.; Kim, J.; Kim, S.-S.; Choi, B.G. $\mathrm{MnO}_{2}$ Nanowire/Biomass-Derived Carbon from Hemp Stem for High-Performance Supercapacitors. Langmuir 2017, 33, 5140-5147. [CrossRef]

47. Wang, L.; Zheng, Y.; Chen, S.; Ye, Y.; Xu, F.; Tan, H.; Li, Z.; Hou, H.; Song, Y. Three-Dimensional Kenaf Stem-Derived Porous Carbon $/ \mathrm{MnO}_{2}$ for High-Performance Supercapacitors. Electrochim. Acta 2014, 135, 380-387. [CrossRef]

48. Wang, $\mathrm{H} . ; \mathrm{Fu}, \mathrm{Q} . ; \mathrm{Pan}, \mathrm{C}$. Green mass synthesis of graphene oxide and its $\mathrm{MnO}_{2}$ composite for high performance supercapacitor. Electrochim. Acta 2019, 312, 11-21. [CrossRef]

49. Nie, G.; Lu, X.; Chi, M.; Gao, M.; Wang, C. General synthesis of hierarchical C/MOx@MnO $2(\mathrm{M}=\mathrm{Mn}, \mathrm{Cu}, \mathrm{Co})$ composite nanofibers for high-performance supercapacitor electrodes. J. Colloid Interface Sci. 2018, 509, 235-244. [CrossRef] 
50. Wang, X.; Chen, S.; Li, D.; Sun, S.; Peng, Z.; Komarneni, S.; Yang, D. Direct Interfacial Growth of MnO $\mathrm{O}_{2} \mathrm{Nanostructure}$ on Hierarchically Porous Carbon for High-Performance Asymmetric Supercapacitors. ACS Sustain. Chem. Eng. 2018, 6, 633-641. [CrossRef]

51. Kang, H.G.; Jeong, J.; Hong, S.B.; Lee, G.Y.; Kim, D.H.; Kim, J.W.; Choi, B.G. Scalable exfoliation and activation of graphite into porous graphene using microwaves for high-performance supercapacitors. J. Alloys Compd. 2019, 770, 458-465. [CrossRef]

52. Bi, Y.; Nautiyal, A.; Zhang, H.; Yan, H.; Luo, J.; Zhang, X. Facile and ultrafast solid-state microwave approach to $\mathrm{MnO}_{2-}$ NW@Graphite nanocomposites for supercapacitors. Ceram. Int. 2018, 44, 5402-5410. [CrossRef]

53. Wang, F.; Zhou, Q.; Li, G.; Wang, Q. Microwave preparation of 3D flower-like $\mathrm{MnO}_{2} / \mathrm{Ni}(\mathrm{OH})_{2} /$ nickel foam composite for high-performance supercapacitors. J. Alloys Compd. 2017, 700, 185-190. [CrossRef]

54. Zhang, X.; Miao, W.; Li, C.; Sun, X.; Wang, K.; Ma, Y. Microwave-assisted rapid synthesis of birnessite-type $\mathrm{MnO}_{2}$ nanoparticles for high performance supercapacitor applications. Mater. Res. Bull. 2015, 71, 111-115. [CrossRef]

55. Zhang, X.; Sun, X.; Zhang, H.; Zhang, D.; Ma, Y. Microwave-assisted reflux rapid synthesis of $\mathrm{MnO}_{2}$ nanostructures and their application in supercapacitors. Electrochim. Acta 2013, 87, 637-644. [CrossRef]

56. Meher, S.K.; Rao, G.R. Enhanced activity of microwave synthesized hierarchical $\mathrm{MnO}_{2}$ for high performance supercapacitor applications. J. Power Sources 2012, 215, 317-328. [CrossRef]

57. Li, Y.; Wang, J.; Zhang, Y.; Banis, M.N.; Liu, J.; Geng, D.; Li, R.; Sun, X. Facile controlled synthesis and growth mechanisms of flower-like and tubular $\mathrm{MnO}_{2}$ nanostructures by microwave-assisted hydrothermal method. J. Colloid Interface Sci. 2012, 369, 123-128. [CrossRef]

58. Bagotsky, V.S.; Skundin, A.M.; Volfkovich, Y.M. Electrochemical Power Sources—Batteries, Fuel Cells, and Supercapacitors; John Wiley \& Sons: Hoboken, NJ, USA, 2015.

59. Audi, A.A.; Sherwood, P. Valence-band X-ray photoelectron spectroscopic studies of manganese and its oxides interpreted by cluster and band structure calculations. Surf. Interface Anal. 2002, 33, 274-282. [CrossRef]

60. Zhou, D.; Lin, H.; Zhang, F.; Niu, H.; Cui, L.; Wang, Q.; Qu, F. Freestanding $\mathrm{MnO}_{2}$ nanoflakes/porous carbon nanofibers for high-performance flexible supercapacitor electrodes. Electrochim. Acta 2015, 161, 427-435. [CrossRef]

61. Ramírez, A.; Hillebrand, P.; Stellmach, D.; May, M.; Bogdanoff, P.; Fiechter, S. Evaluation of $\mathrm{MnOx} \mathrm{Mn}_{2} \mathrm{O}_{3}$, and $\mathrm{Mn}_{3} \mathrm{O}_{4}$ Electrodeposited Films for the Oxygen Evolution Reaction of Water. J. Phys. Chem. C 2014, 118, 14073-14081. [CrossRef]

62. NIST X-ray Photoelectron Spectroscopy Database. Available online: https://srdata.nist.gov/xps/ (accessed on 11 May 2021).

63. Ilton, E.S.; Post, J.E.; Heaney, P.J.; Ling, F.T.; Kerisit, S.N. XPS determination of Mn oxidation states in Mn (hydr)oxides. Appl. Surf. Sci. 2016, 366, 475-485. [CrossRef]

64. Baer, D.R.; Artyushkova, K.; Cohen, H.; Easton, C.D.; Engelhard, M.; Gengenbach, T.R.; Greczynski, G.; Mack, P.; Morgan, D.J.; Roberts, A. XPS guide: Charge neutralization and binding energy referencing for insulating samples. J. Vac. Sci. Technol. A 2020, 38, 031204. [CrossRef]

65. Beyazay, T.; Oztuna, F.E.S.; Unal, U. Self-Standing Reduced Graphene Oxide Papers Electrodeposited with Manganese Oxide Nanostructures as Electrodes for Electrochemical Capacitors. Electrochim. Acta 2019, 296, 916-924. [CrossRef]

66. Biesinger, M.C.; Payne, B.P.; Grosvenor, A.P.; Lau, L.W.; Gerson, A.R.; Smart, R.S. Resolving surface chemical states in XPS analysis of first row transition metals, oxides and hydroxides: Cr, Mn, Fe, Co and Ni. Appl. Surf. Sci. 2011, 257, 2717-2730. [CrossRef]

67. Grissa, R.; Martinez, H.; Cotte, S.; Galipaud, J.; Pecquenard, B.; Le Cras, F. Thorough XPS analyses on overlithiated manganese spinel cycled around the 3V plateau. Appl. Surf. Sci. 2017, 411, 449-456. [CrossRef]

68. Dong, X.; Shen, W.; Gu, J.; Xiong, L.; Zhu, Y.; Li, A.H.; Shi, J. $\mathrm{MnO}_{2}$-Embedded-in-Mesoporous-Carbon-Wall Structure for Use as Electrochemical Capacitors. J. Phys. Chem. B 2006, 110, 6015-6019. [CrossRef]

69. Singu, B.S.; Hong, S.E.; Yoon, K.R. Ultra-thin and ultra-long $\alpha-\mathrm{MnO}_{2}$ nanowires for pseudocapacitor material. J. Solid State Electrochem. 2017, 21, 3215-3220. [CrossRef]

70. Yang, Y.; Niu, H.; Qin, F.; Guo, Z.; Wang, J.; Ni, G.; Zuo, P.; Qu, S.; Shen, W. $\mathrm{MnO}_{2}$ doped carbon nanosheets prepared from coal tar pitch for advanced asymmetric supercapacitor. Electrochim. Acta 2020, 354, 136667. [CrossRef]

71. Edison, T.N.J.I.; Atchudan, R.; Karthik, N.; Xiong, D.; Lee, Y.R. Direct electro-synthesis of $\mathrm{MnO}_{2}$ nanoparticles over nickel foam from spent alkaline battery cathode and its supercapacitor performance. J. Taiwan Inst. Chem. Eng. 2019, 97, 414-423. [CrossRef]

72. Xue, C.; Hao, Y.; Luan, Q.; Wang, E.; Ma, X.; Hao, X. Porous manganese dioxide film built from arborization-like nanoclusters and its superior electrochemical supercapacitance with attractive cyclic stability. Electrochim. Acta 2019, 296, 94-101. [CrossRef] 